\title{
Susceptibility to and impact of interpersonal influence in an investment context
}

\author{
A. O. I. Hoffmann • T. L. J. Broekhuizen
}

Received: 20 September 2007 / Accepted: 18 December 2008 / Published online: 20 January 2009

(C) The Author(s) 2009. This article is published with open access at Springerlink.com

\begin{abstract}
This paper demonstrates the relevance of consumers' susceptibility to interpersonal influence (CSII) in an investment context. In Study 1, a survey of individual investors, investment-related knowledge, psycho-social risks, and social needs emerge as antecedents that explain investors' susceptibility to informational and normative influence. In turn, susceptibility to normative influences increases transaction frequency, whereas susceptibility to informational influences decreases transaction frequency. The experiments in Studies 2 and 3 indicate the impact of interpersonal influences on consumers' investment decisions in a voluntary (free choice) and involuntary (confrontation) setting and check whether CSII moderates the impact of interpersonal influences. Consumers' investment choices are consistently influenced by the information and opinions of others, whereas CSII only strengthens the impact of interpersonal influence in a voluntary informational setting.
\end{abstract}

We thank the editor, David W. Stewart, the four anonymous reviewers, and Arie Dijkstra, Peter C. Verhoef, Martin G. M. Wetzels, Debra Trampe, Mirjam A. Tuk, and Robert P. Merrin for their useful comments on previous versions of this article. Any remaining errors are our own.

A. O. I. Hoffmann ( $\square)$

Department of Finance,

Faculty of Economics and Business Administration,

University of Maastricht,

P.O. Box 616, 6200 MD Maastricht, The Netherlands

e-mail: a.hoffmann@finance.unimaas.nl

A. O. I. Hoffmann

Network for Studies on Pensions, Aging, and Retirement (Netspar), P.O. Box 90153, 5000 LE Tilburg, The Netherlands

T. L. J. Broekhuizen

Department of Innovation Management and Strategy,

Faculty of Economics and Business, University of Groningen,

P.O. Box 800, 9700 AV Groningen, The Netherlands
Keywords Susceptibility to interpersonal influence . Investments · Reference-group influence

\section{Introduction}

"We are influenced by others in almost every activity, and this includes investment and financial transactions."

\section{—Hirschleifer \& Teoh 2003: 25}

Consumers often use social information when making their decisions, especially in uncertain situations (Mitchell and McGoldrick 1996). The extent to which social information affects consumers' decisions depends on their susceptibility to interpersonal influence.

Susceptibility to interpersonal influence is a consumer trait that varies across individuals (McGuire 1968). The important effects of consumers' susceptibility to interpersonal influence (CSII) on their decision-making processes have been documented extensively in consumer behavior and marketing literature (Bearden et al. 1989, 1990; Bristol and Mangleburg 2005; Kropp et al. 1999; Mascarenhas and Higby 1993; Mourali et al. 2005; Ratner and Kahn 2002). However, none of these studies address consumers' investment decisions. Existing CSII studies focus on conspicuous and socially visible products such as cars (Bearden and Rose 1990), apparel (Meyer and Anderson 2000; Miller 1998), or women's cosmetics (Chao and Schor 1998). To the best of our knowledge, this paper is first to demonstrate the relevance of CSII for less conspicuous and visible product categories in general by examining its effects in an investment setting. 
Although investments' low visibility may suggest they are privately consumed products, the opening quote suggests that social information could play an important role in consumers' investment decisions. On the one hand, consumers often deliberately increase the visibility of their investment decisions and expose themselves to public scrutiny by engaging in related social interactions, such as joining investment clubs (Barber and Odean 2000), or discussing their investment decisions and performance with other stock market participants (Hong et al. 2004). On the other hand, consumer research argues that both the real and the imagined presence of others significantly influence people's behavior (Kropp et al. 1999: 537). Even in the absence of direct visibility, investors may be concerned about which investments will make a good impression on others.

Studying susceptibility to and the impact of interpersonal influences in an investment context is relevant for marketing research and practice for several reasons. First, no theory of consumption can be complete without including an understanding of how consumers manage their wealth (Zhou and Pham 2004). Consumers' current investment choices have considerable consequences for their current and future consumption (cf. Browning and Crossley 2001), so from this perspective, it seems surprising that marketing research has paid so little attention to investment decisions (Johnson and Tellis 2005; Johnson et al. 2005; Zhou and Pham 2004), and even less attention to how they are influenced by others. Second, individual investors hold about $50 \%$ of U.S. equity (Odean and Barber 2000), which means consumers' investment decisions can help explain the overall dynamics of financial markets. This topic is especially important with regard to the population's aging demographics and the increased self-responsibility of consumers for their retirement accounts. Third, CSII has important consequences for consumer behavior. Recent studies on consumer innovativeness (Clark and Goldsmith 2006; Steenkamp and Gielens 2003), for example, show that consumers who are susceptible to the influence of others are less inclined to purchase innovative products, such as new financial services, early. Considering the size of the financial services industry, the failure of approximately $50 \%$ of all financial innovations (Edgett 1994), and the benefits of new products for financial service providers (Storey and Easingwood 1999), marketers must begin to study the role of CSII in an investment context. Fourth, examining CSII in an investment context has societal relevance. Consumers who are more susceptible to social influences are more likely to engage in conformist behavior, which affects asset prices (De Bondt 1998) and may result in herding behavior (Bikhchandani et al. 1992; Hirschleifer 2001; Shiller 1995). Herding is considered one of the driving forces behind the Internet Bubble (Kindleberger 2000) and can also be associated with the recent turmoil on financial markets sparked by the "credit crunch". Policymakers worry that herding can destabilize markets and increase the fragility of financial systems (Bikhchandani and Sharma 2000). Therefore, it is important to investigate what kind of people are most likely to be highly influenced by others with respect to their investment behavior and engage in conformist or herding behavior.

We investigate, through a survey study and two experimental studies, the kinds of consumers who are susceptible to interpersonal influence and how they react to those interpersonal influences. The survey study identifies the general traits and dispositions that make consumers most susceptible to interpersonal influence and clarifies the effect of this susceptibility on the number of investment transactions in which they participate. In the two experimental studies, we investigate the impact of the social environment on actual investment behaviors by confronting subjects with informational and normative influences (Study 2) or giving them the option to receive interpersonal information or opinions (Study 3). Thus, we investigate the effects of both passively receiving and actively requesting interpersonal influence. In both experiments, we test whether CSII moderates the effect of interpersonal influence on consumers' investment decisions.

In so doing, we contribute to the literature in several ways. Most importantly, this is the first paper to empirically investigate CSII and the effects of interpersonal influences for a less conspicuous and visible product. In addition, by taking the antecedents and consequences of CSII into account, we add to the emerging but limited body of research that positions CSII in a nomological net (Batra et al. 2001). Although current literature associates CSII with a variety of variables, such as self-esteem, attention to social comparison information (ATSCI), motivation to comply, public self-consciousness, and consumer innovativeness (Bearden et al. 1989, 1990; Bearden and Rose 1990; Clark and Goldsmith 2006; Lascu et al. 1995; Steenkamp and Gielens 2003), it is uncommon that these accumulated research findings appear united in a theoretical framework. Finally, we use experimental data for the first time to show how interpersonal influences affect consumers' investment decisions. Existing studies are often limited to involuntary settings, which means they impose interpersonal influences on subjects (Burnkrant and Cousineau 1975; LaTour and Manrai 1989). This article also examines the impact of interpersonal influences in a voluntary setting.

\section{Study 1}

Our goal for Study 1 is to place the CSII concept within a conceptual framework and test it with an empirical survey. 
We present the theoretical background, conceptual model, hypotheses, and results next.

\section{Theoretical background}

The most widely used measure of CSII is that developed by Bearden et al. (1989, 1990), which distinguishes between susceptibility to informational influences (SII) and susceptibility to normative influences (SNI). The former reflects a person's tendency to accept information from others as credible evidence about reality (Deutsch and Gerard 1955). Informational influence results from actively requesting information from knowledgeable others or passively observing others (Park and Lessig 1977). It operates through the process of internalization, which occurs if information from others increases an individual's knowledge about some aspect of the environment. Informational influence is driven by a desire to form accurate interpretations about reality in order to make more informed decisions and behave correctly (Cialdini and Goldstein 2004). SNI reflects an individual's tendency to comply with the positive expectations of others (Deutsch and Gerard 1955: 629) and is driven by an individual's desire to enhance one's self-image by association with a reference group or because individuals want to achieve rewards or avoid punishments mediated by others.

Previous studies relate the CSII scale to several consumer factors, including demographics, general psychographic traits, domain-specific knowledge, personal values, and situational factors (Batra et al. 2001; Bearden et al. 1989, 1990; Bearden and Rose 1990; Clark and Goldsmith 2005; D'Rozario and Choudhury 2000; Lascu et al. 1995; Mangleburg et al. 2004). The aim of Study 1 is not to provide an exhaustive list of potential correlates of investors' susceptibility to interpersonal influence, but rather to place this concept within a theoretical framework by incorporating its primary antecedents and consequences.

Conceptual model

As we indicate in Fig. 1, Study 1 uses a hierarchical trait model in which general traits and dispositions causally precede more situation-specific traits, which then influence a larger set of secondary traits and actions (cf. Batra et al. 2001). In our conceptual model, susceptibility to interpersonal influence acts as a situation-specific trait, because it represents a "weak trait" (McGuire 1968: 1132) with low intercorrelations across situations and behaviors (Batra et al. 2001). A person's influenceability often appears as a consequence of personality variables, such as self-esteem or social anxiety (Batra et al. 2001; Bearden et al. 1990; McGuire 1968). Anxiety originating from a lack of knowledge or perceptions of psychological or social risk therefore drives a person's influenceability. Moreover, personal values, such as social needs, are assumed to be important antecedents or causes of situation-specific traits such as someone's susceptibility to interpersonal influence (Batra et al. 2001). Therefore, we argue that consumers' general traits and dispositions such as their investmentrelated knowledge, perceptions of social and psychological risk, and strength of socially oriented needs determine the more specific and situation-dependent trait of susceptibility to interpersonal influences, which leads to even more specific outcomes or behaviors, such as transaction frequency.

The dimensions of CSII in an investment context thus can be explained by motivations to increase the accuracy of investment decisions by building knowledge through social interactions, decrease the potential for social embarrassment or psychological discomfort by learning about and conforming to socially accepted behavior, and fulfill social needs by creating and maintaining valuable relationships.

\section{Hypotheses}

\section{Antecedents of consumers' susceptibility to interpersonal influence}

Domain-specific knowledge In an investment context, domain-specific knowledge relates to consumers' familiarity with and expertise in making investment decisions (cf. Alba and Hutchinson 1987). The amount of domainspecific knowledge determines product decisions (Alba and Hutchinson 1987) and negatively influences suscepti-
Figure 1 Conceptual model of Study 1 .

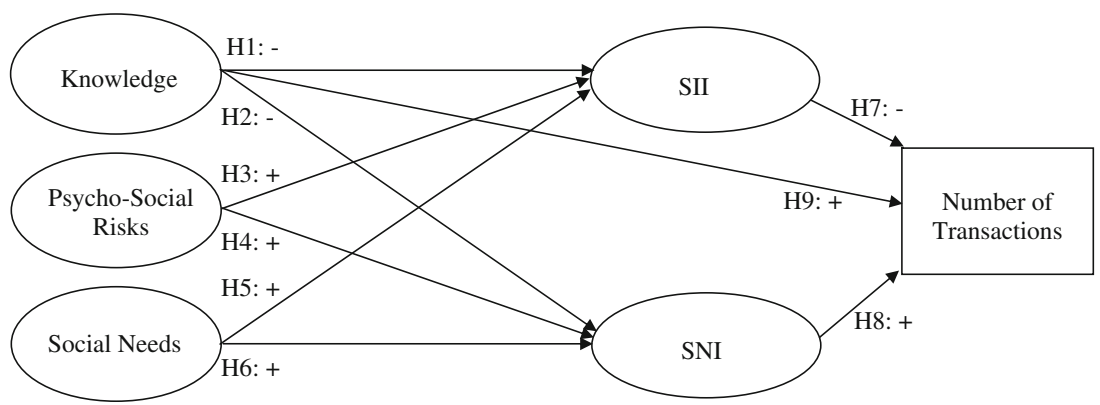


bility to both informational and normative interpersonal influence (Furse et al. 1984; Gilly et al. 1998; Mangleburg et al. 2004). Individuals with more knowledge tend to be more confident about making correct decisions and demonstrate less interest in others' information and opinions (Bearden et al. 1990; Clark and Goldsmith 2006; Kahle 1995; Locander and Hermann 1979). That is, knowledgeable consumers depend less on others to obtain relevant product information, but they also depend less on others with respect to the normative aspects of decision making. They tend to be more self-confident and have higher selfesteem, which relates negatively to the need for social approval (Cox and Bauer 1964). Hence, more knowledgeable consumers should be less susceptible to both informational and normative interpersonal influences.

Conversely, individuals with less knowledge are more susceptible to informational and normative interpersonal influences. On the one hand, those with less knowledge may doubt their ability to make good decisions and perceive higher risks (Alba and Hutchinson 1987), so to reduce this risk, they may feel more compelled to ask knowledgeable others for advice and rely more strongly on this advice compared with those consumers who know more and perceive less risk (Festinger 1954; Furse et al. 1984; Gilly et al. 1998; Mangleburg et al. 2004; Mitchell and McGoldrick 1996). On the other hand, individuals with less knowledge lack a sense of personal adequacy and may suffer low self-confidence and self-esteem, which often makes them excessively fearful of social disapproval and strongly motivated to conform to others' demands or suggestions (Janis 1954; Cox and Bauer 1964). Their compliance can be interpreted as a defensive form of behavior that permits these consumers to agree with everyone in an attempt to guarantee that nobody will be displeased with them (Janis 1955).

H1. The amount of consumers' investment-related knowledge is negatively associated with their susceptibility to informational influences when making investment decisions.

H2. The amount of consumers' investment-related knowledge is negatively associated with their susceptibility to normative influences when making investment decisions.

Psychological and social risk In addition to product or performance risk, consumers may also experience social and psychological risk that discourages them from engaging in behaviors that are not accepted by their reference group or that conflict with their personality or self-image (Cialdini and Goldstein 2004; Sirgy 1982, 1985). Beyond the possibility of losing money (product or performance risk), consumers may be anxious that their peers will not accept their investment choices or that they will embarrass themselves in public or "not fit in" with specific reference groups (social risk). Moreover, consumers run the risk of experiencing psychological discomfort or frustration if their actions are not consistent with their self-concept or selfimage (psychological risk). In general, status-conscious consumers perceive greater psycho-social risks, because they are more concerned about their self-image and worried about not fitting in, which makes them more likely to be affected by interpersonal influences (O'Cass and McEwen 2004). Research into the concept of purchase pals indicates that teens frequently shop together and adjust their decisions according to the information and opinions of relevant others to reduce not only their functional (product or performance) risks but also the perceived psycho-social risks associated with purchases (Kiecker and Hartman 1993).

A recent study by Yim et al. (2007) investigates the role of multiple referents on the evaluations of services. They suggest that the evaluation of services depends on the approval of others, and in particular on how well the service fits with the self-image. They argue that higher levels of self-image congruity (i.e., services that more closely match one's self-image) are associated with lower levels of psychological discomfort or risk (cf. Sirgy 1985) and less consideration for attractive alternatives. In a similar vein, Kleijnen et al. (2005) find that consumers with low selfimage congruence are more susceptible to their surroundings than are consumers with high self-image congruence when adopting service innovations.

This discussion implies that consumers who perceive psycho-social risks may actively seek and rely on information from and the opinions of social others to reduce their risk. That is, consumers' perception of psycho-social risks should relate to SII and SNI. First, consumers who perceive greater psycho-social risks tend to be more susceptible to informational influence, because they are motivated to build their knowledge about socially accepted behaviors and the consequences of their actions for their self-concept (Cialdini and Goldstein 2004). These consumers ask relevant others so that they may learn about the correct way to behave and avoid future social embarrassment or psychological discomfort. Therefore, psycho-social risks are positively associated with the informational dimension of interpersonal influence, operating through internalization (Burnkrant and Cousineau 1975). Second, consumers who perceive greater psycho-social risks want to fit in and seek the approval of social others by currently complying with their social norms. As such, psycho-social risks should be positively associated with the normative dimension of interpersonal influence, operating through processes of identification (maintaining a positive self-concept) and 
compliance (achieving social rewards) (Burnkrant and Cousineau 1975).

H3. Consumers' level of perceived psycho-social risk is positively associated with their susceptibility to informational influences when making investment decisions.

H4. Consumers' level of perceived psycho-social risk is positively associated with their susceptibility to normative influences when making investment decisions.

Social needs Consumers engage in social interactions not only to reduce perceived purchase risk but also to fulfill their social needs. Humans are fundamentally motivated to create and maintain meaningful and rewarding social relationships (Maslow 1954). The strength of social needs differs across individuals, and just as personal values do, they guide individuals' behavior by affecting the criteria used to evaluate actions, people, and events. Personal or human values include internal values (e.g., self-fulfillment, sense of accomplishment, self-respect) and social or external values (e.g., being well-respected, having warm relationships with others) (Batra et al. 2001). Values are motivational in nature and provide important antecedents of situation-specific predispositions, such as CSII (cf. Batra et al. 2001). Consumers' importance of social values is positively related to SNI (Batra et al. 2001; Kropp et al. 1999). On the basis of these arguments, we expect consumers with stronger social needs to be more susceptible to informational and normative interpersonal influences when they invest than are consumers who have less explicit social needs. Consumers with stronger social needs tend to be more open to and derive greater value from social interactions, such as investment-related interpersonal information exchanges (SII). Moreover, they prefer buying stocks that they expect their reference group to approve of or that enable them to identify with others and thus create and maintain rewarding relationships (SNI).

H5. The strength of consumers' social needs is positively associated with their susceptibility to informational influences when making investment decisions.

H6. The strength of consumers' social needs is positively associated with their susceptibility to normative influences when making investment decisions.

\section{Consequences of consumers' susceptibility to interpersonal} influence

This study examines the effect of consumers' susceptibility to interpersonal influence on their yearly number of investment transactions, which is an important variable for consumers and policymakers alike, because overtrading generally results in poor performance through the accumulation of transaction costs (Odean and Barber 2000). Furthermore, through commissions, consumers' transaction frequency directly affects banks' and brokerage firms' profitability.

Existing literature presents mixed and inconclusive results regarding the possible effect of CSII on transaction frequency (Mangleburg et al. 2004). Prior research finds a negative relationship between CSII and willingness to adopt new products, which may relate to hesitation to trade. Individuals who are more susceptible to interpersonal influences are less willing to make an adoption decision until a majority of relevant others also supports the new concept (Clark and Goldsmith 2006; Steenkamp and Gielens 2003). Conversely, we can assume a positive relationship between CSII and transaction frequency, because consumers who are susceptible to interpersonal influence are more receptive to environmental cues and more likely to act on this social information. By either conforming to or deviating from this new information, they may trade more frequently.

On the basis of social comparison theory (Festinger 1954), we hypothesize a negative relationship between SII and transaction frequency. That is, consumers susceptible to informational influences may-after requesting and receiving information from other, more knowledgeable peoplereceive reinforcement of their belief that they have insufficient knowledge to make well-informed investment decisions or obtain contradictory information. They can limit the impact of wrong decisions by minimizing their transactions, and they might be informed by others that a buy-and-hold strategy is best.

We hypothesize a positive relationship between SNI and transaction frequency, because consumers who are susceptible to normative influence are more likely to get carried away by others' opinions and may transact to reinforce their social bonds or comply with others' expectations. Then, SNI may lead to chameleon-like changes in response to any new source of persuasive influence (Janis 1955), which suggests more transactions.

H7. Consumers' susceptibility to informational influence is negatively associated with the number of investment transactions they make.

H8. Consumers' susceptibility to normative influence is positively associated with the number of investment transactions they make.

Finally, we expect a direct relationship between consumers' level of investment-related knowledge and the number of investment transactions. More knowledgeable consumers have more expertise and are more familiar with investing (cf. Alba and Hutchinson 1987), which likely is 
associated with lower perceptions of risk, easier access to financial markets, more involvement with the product category, and a higher likelihood to transact.

H9. Consumers' level of investment-related knowledge is positively associated with the number of investment transactions they make.

Research approach: Study 1

\section{Method}

We used a survey approach to collect data from individual investors and test the hypotheses of our conceptual model (Fig. 1). We developed and tested an online questionnaire among 78 undergraduate and graduate students. After revising the questionnaire wording and layout, we asked a panel of five academics to confirm whether the items closely resembled the intended constructs. Next, we collected the empirical data through an online questionnaire that targeted visitors to four investment-related Web sites, selected because they attempt to attract respondents with various levels of experience and backgrounds. The call to participate provided a summary of the purpose of the study and a link to the online questionnaire. We carefully checked the final sample for duplicates using respondents' IP address and contact details. Furthermore, we told respondents that their responses would remain anonymous and that all data would be treated confidentially.

\section{Sample}

The net sample consisted of 287 investors with an average age of 53 years $(\mathrm{SD}=13)$. Twelve percent of the respondents are women, and more than two-thirds have at least a college degree. These respondents note a considerable length of investing experience $(M=16$ years, $\mathrm{SD}=11)$ and, on average, transact 77 times per year $(\mathrm{SD}=122$, median $=30)$. Almost all respondents (98\%) invest for their own accounts. The dominant purchasing channels that these investors use are as follows: $56 \%$ online brokers, $36 \%$ banks, $4 \%$ direct telephone order lines, and $4 \%$ expert advice. The average portfolio size is $€ 207,000$ (approximately $\$ 310,500$ ) with a median of $€ 70,000$ (approximately $\$ 105,000$ ). Among the sample, $20 \%$ belong to an investment club.

To investigate potential selection bias, we compared these sample characteristics with the characteristics of the general population of investors with direct investments in the Dutch stock market (VEB 2002). Our respondents are slightly older (53 years compared with 48 years) and more likely to be men ( $88 \%$ compared with $71 \%$ ). The modal portfolio size, however, equals that of the general investment population, at $€ 50,000$. Also, the median portfolio size closely corresponds with estimates from the Dutch National Bank (2006) that show an average portfolio size per investing household of $€ 70,000$. The respondents' transaction frequency also matches another Dutch sample (Bauer et al. 2007). In conclusion, the sample appears similar to the overall population of Dutch investors with regard to selected background characteristics, though we also note that our sample consists of fairly experienced investors.

\section{Measures and research instrument}

All items use five- or seven-point Likert scales to measure the relevant constructs (Table 1). Respondents' susceptibility to interpersonal influence employs the CSII scale proposed by Bearden et al. $(1989,1990)$. The SII measure includes all four items of the original scale, whereas the SNI measure for our study drops one of the original eight items because it explicitly refers to purchasing the latest fashion. This item was potentially distracting for our respondents and irrelevant to the investment context.

Following Bloch et al. (1989), we measure domainspecific knowledge with self-reported measures. The two items measuring psychological and social risk come directly from work by Kaplan et al. (1974). To measure respondents' strength of social needs, we use items from Cheek and Buss's (1981) sociability study.

We employ standard psychometric procedures to test the reliability and validity of the scales (Netemeyer et al. 2003; Nunnally and Bernstein 1994). After performing reliability analyses, we test the validity of the constructs with confirmatory factor analyses (CFA) using AMOS 7 (see Table 1). As a result, we remove two items from the SNI scale that indicated low loadings $(<0.50)$.

The final measurement model using maximum likelihood estimation demonstrates acceptable fit $\left(\chi^{2} / d f=1.68\right.$, GFI $=$ 0.94, CFI $=0.96, \mathrm{RFI}=0.89$, TLI $=0.95$, RMSEA $=0.049){ }^{1}$ We also find evidence of convergent validity and unidimensionality, because each item loads significantly $(p<0.001)$ on its assigned factor and reveals insignificant cross-loadings. Next, the average variance extracted (AVE) of all constructs was greater than 0.50 with the exception of the SII scale, which falls marginally below the required level (Fornell and Larcker 1981). To establish discriminant validity, we first note that the intercorrelations between the latent factors

\footnotetext{
${ }^{1}$ Previous research has subdivided the concept of normative influences into value-expressive and utilitarian influences, but then collapsed them into one normative dimension after extensive empirical analyses (Bearden et al. 1989, 1990; Mangleburg et al. 2004). We test for a three-factor model that divides susceptibility to normative influence into two dimensions: utilitarian and value-expressive. The two-factor solution results in better fit indices, and the three-factor solution leads to inadmissible solutions (e.g., negative error terms, correlation between value-expressive and utilitarian greater than 1). Therefore, we prefer the two-factor model.
} 
Table 1 Measurement model results of Study 1

\begin{tabular}{|c|c|c|c|c|}
\hline Construct & Item wording $^{\mathrm{a}}$ & SL & $\alpha / \mathrm{CR}$ & AVE \\
\hline \multirow[t]{2}{*}{$\begin{array}{l}\text { Domain-specific knowledge } \\
\text { (Bloch et al. 1989) }\end{array}$} & $\begin{array}{l}\text { Knowl1: How would others characterize you with regard to the level of } \\
\text { KNOWLEDGE you have about investing? (1=Very little knowledge, } \\
5=\text { Very much knowledge) }\end{array}$ & $0.79(-)$ & $0.87 / 0.88$ & 0.79 \\
\hline & $\begin{array}{l}\text { Knowl2: How would others characterize you with regard to the level of } \\
\text { EXPERIENCE you have with investing? (1=Very limited experience, } \\
\text { 5=Very extended experience) }\end{array}$ & $0.98(6.39)$ & & \\
\hline \multirow[t]{2}{*}{$\begin{array}{l}\text { Psycho-social risk } \\
\text { (Kaplan et al. 1974) }\end{array}$} & $\begin{array}{l}\text { Psych/socrisk1: What is the probability that an investment in an } \\
\text { unfamiliar stock will lead to a PSYCHOLOGICAL LOSS for you } \\
\text { because it would not fit well with your self image or self-concept? } \\
(1=\text { Very unlikely, } 7=\text { Very likely) }\end{array}$ & $0.64(-)$ & $0.71 / 0.74$ & 0.59 \\
\hline & $\begin{array}{l}\text { Psych/socrisk2: What is the probability that an investment in an } \\
\text { unfamiliar stock will lead to a SOCIAL LOSS for you because others } \\
\text { would think less highly of you? ( } 1=\text { Very unlikely, } 7=\text { Very likely) }\end{array}$ & $0.88(5.22)$ & & \\
\hline \multirow[t]{2}{*}{$\begin{array}{l}\text { Social needs } \\
\text { (Cheek and Buss 1981) }\end{array}$} & $\begin{array}{l}\text { SocNeed1: I invest because I like to participate in investment related } \\
\text { conversations with others }\end{array}$ & $0.75(7.15)$ & $0.74 / 0.74$ & 0.59 \\
\hline & SocNeed2: I invest because I like to affiliate with other investors & $0.79(-)$ & & \\
\hline \multirow{4}{*}{$\begin{array}{l}\text { Susceptibility to } \\
\text { informational influence (SII) } \\
\text { (Bearden et al. 1989) }\end{array}$} & $\begin{array}{l}\text { SII1: I frequently gather information about (type of) stock from friends } \\
\text { or family before I invest in them }\end{array}$ & $0.69(10.37)$ & $0.78 / 0.78$ & 0.47 \\
\hline & $\begin{array}{l}\text { SII2: To make sure I buy the right stock, I often observe what other } \\
\text { investors invest in }\end{array}$ & $0.62(9.47)$ & & \\
\hline & $\begin{array}{l}\text { SII3: I often consult other people to help choose the best stock to } \\
\text { invest in }\end{array}$ & $0.69(9.99)$ & & \\
\hline & $\begin{array}{l}\text { SII4: If I have little experience with a (type of) stock, I often ask my } \\
\text { friends and acquaintances about the stock }\end{array}$ & $0.77(-)$ & & \\
\hline \multirow{5}{*}{$\begin{array}{l}\text { Susceptibility to normative } \\
\text { influence (SNI) } \\
\text { (Bearden et al. 1989) }\end{array}$} & $\begin{array}{l}\text { SNI1: I like to know what investment decisions make good impressions } \\
\text { on others }\end{array}$ & $0.66(11.50)$ & $0.86 / 0.87$ & 0.57 \\
\hline & $\begin{array}{l}\text { SNI2: I generally purchase those stocks that I think others will } \\
\text { approve of }\end{array}$ & $0.70(12.40)$ & & \\
\hline & $\begin{array}{l}\text { SNI3: I often identify with other people by purchasing or selling the } \\
\text { same stocks they sell or purchase }\end{array}$ & $0.81(14.76)$ & & \\
\hline & $\begin{array}{l}\text { SNI4: I achieve a sense of belonging by purchasing or selling the same } \\
\text { stocks that others purchase or sell }\end{array}$ & $0.79(14.19)$ & & \\
\hline & $\begin{array}{l}\text { SNI5: If others can see in which stocks I invest, I often invest in stocks } \\
\text { that they invest in }\end{array}$ & $0.81(-)$ & & \\
\hline
\end{tabular}

${ }^{\text {a }}$ All items, unless otherwise noted, use five-point Likert scales, anchoring at $1=$ totally disagree and $5=$ totally agree $S L$ maximum likelihood standardized loadings with $t$-values in parentheses, $\alpha$ Cronbach's alphas, $C R$ composite reliabilities, $A V E$ average variance extracted

( \pm two standard errors) do not include unity (Anderson and Gerbing 1988) (Table 2). Furthermore, the AVE of each latent construct is greater than the squared correlations between any set of two constructs (Fornell and Larcker 1981). Finally, the composite reliabilities range from 0.74 to 0.88 , which indicate high levels of construct reliability (Bagozzi and Yi 1988). These analyses demonstrate that our scales have sufficient levels of reliability, unidimensionality, convergent validity, and discriminant validity.

Results

We depict the structural model of Study 1 and the significance of its relationships in Fig. 2. The data confirm all hypotheses $(\mathrm{H} 1-\mathrm{H} 9)$. The structural model fits the data well $\left(\chi^{2} / d f=2.00, \mathrm{GFI}=0.92, \mathrm{CFI}=0.94, \mathrm{RFI}=0.87, \mathrm{TLI}=\right.$
0.93, RMSEA $=0.059)$ and explains a reasonable amount of the variance in SNI $\left(R^{2}=36.6 \%\right)$ and SII $\left(R^{2}=38.1 \%\right)$. The antecedents account for $9.9 \%$ of the variance of consumers' transaction frequency. The maximum variable inflation factor (VIF) for each independent variable in a set of regression analyses is 1.35 , which suggests some but not strong multicollinearity. ${ }^{2}$

\footnotetext{
${ }^{2}$ We also investigated the influence of age, gender, and investment club membership on SII and SNI. The means do not differ across age categories for SII $(F(3,283)=0.82, p=0.48)$ or SNI $(F(3,283)=0.30$, $p=0.83$ ). The means of SII and SNI also did not differ significantly between men and women according to a $t$-test $(p>0.10)$. Members of investment clubs are significantly more susceptible to both SII $(t(283)=$ $2.58, p=0.01)$ and SNI $(t(283)=1.96, p=0.05)$. Because performing the structural analyses without the investment club members provides very similar results, we use the complete data set in our subsequent analyses.
} 
Table 2 Construct correlations and AVE of Study 1

\begin{tabular}{lllllll}
\hline Construct & Knowledge & Psycho-social risk & Social needs & SII & SNI & Number of transactions \\
\hline Knowledge & $\mathbf{0 . 8 9}$ & & & & & \\
Psycho-social risk & $0.04(0.08)$ & $\mathbf{0 . 7 7}$ & & & & \\
Social needs & $0.15(0.09)$ & $0.24^{* * *}(0.07)$ & $\mathbf{0 . 7 7}$ & & \\
SII & $-0.08(0.07)$ & $0.31^{* * *}(0.08)$ & $0.47 * * *(0.08)$ & $\mathbf{0 . 6 9}$ & & \\
SNI & $-0.06(0.07)$ & $0.42^{* * *}(0.07)$ & $0.40 * * *(0.07)$ & $0.62^{* * *}(0.06)$ & $\mathbf{0 . 7 5}$ & \\
\# Transactions & $0.24^{* *}(0.08)$ & $-0.01(0.07)$ & $-0.03(0.06)$ & $-0.15^{* *}(0.06)$ & $0.01(0.06)$ & N/A \\
\hline
\end{tabular}

The numbers below the diagonal represent the correlations between two latent constructs; the numbers in parentheses refer to the standard errors The numbers in bold represent the square root of the average variance extracted (AVE)

Standard errors were derived from bootstrapping with 500 replications

$* p<0.05 ; * * p<0.01 ; * * * p<0.001$

Consistent with previous studies in other contexts (Gilly et al. 1998; Mangleburg et al. 2004; Park and Lessig 1977), we find that consumers' level of domain-specific knowledge is negatively associated with both SII (H1: $\beta=-0.19, p=$ $0.005)$ and SNI (H2: $\beta=-0.16, p=0.010)$ in an investment context. The results also support the proposed positive associations between psycho-social risk and SII (H3: $\beta=$ $0.25, p<0.001)$ and SNI (H4: $\beta=0.37, p<0.001)$. Furthermore, consumers' strength of social needs appears strongly positively related to both SII (H5: $\beta=0.40, p<0.001)$ and SNI (H6: $\beta=0.51, p<0.001$ ).

Since the dimensions of SII and SNI are conceptually different and operate through different mechanisms with different goals (e.g., Cialdini and Trost 1998), the relative strength of the antecedents may differ across these dimensions. In particular, SII relates more strongly to personal values, such as self-fulfillment and self-respect, because it is driven by the motivations to learn and increase the accuracy of investment decisions, whereas SNI appeals to social values, such as having warm relationships with others and achieving a sense of belonging, which are inherently linked to the motivations to fulfill socially oriented needs (Batra et al. 2001). Therefore, we expect knowledge to relate more strongly to SII than to SNI, and social needs should relate more strongly to SNI than to SII. We used the procedure suggested by Chin (2000) to test the differences between these relationships by analyzing the differences in the strength of the unstandardized path coefficients. The results confirm our expectations. Knowledge has a stronger influence on SII than on SNI $\left(B_{\text {know } \rightarrow \text { SII }}=-0.22\right.$ vs. $\left.B_{\text {know } \rightarrow \mathrm{SNI}}=-0.13, t=16.4, p<0.001\right)$, and social needs have a more pronounced effect on SNI than on SII $\left(B_{\text {socneeds } \rightarrow \text { SNI }}=0.48\right.$ vs. $B_{\text {socneeds } \rightarrow \text { SII }}=0.26, t=39.3$, $p<0.001)$.

We also find support that SII is negatively associated (H7: $\beta=-0.22, p=0.002$ ) and SNI is moderately positively associated (H8: $\beta=0.15, p=0.030)$ with the number of transactions. Because these results contradict findings by Mangleburg et al. (2004), who find that SII positively and SNI negatively influences teens' shopping frequency with friends, we call for replication studies that can help generalize these results.

Finally, we find that knowledge (H9: $\beta=0.22, p<0.001$ ) is positively associated with transaction frequency.

\section{Study 2}

Study 2 tests how consumers' investments decisions are altered when they are confronted with informational versus normative interpersonal influences in an involuntary setting. This study also tests whether CSII moderates the impact of interpersonal influences.
Figure 2 Structural model results of Study 1. Notes: a. ${ }^{*} p<0.05, * * p<0.01$; $* * * p<0.001$. b. Standardized coefficients are shown. c. Numbers in bold are squared multiple correlations.

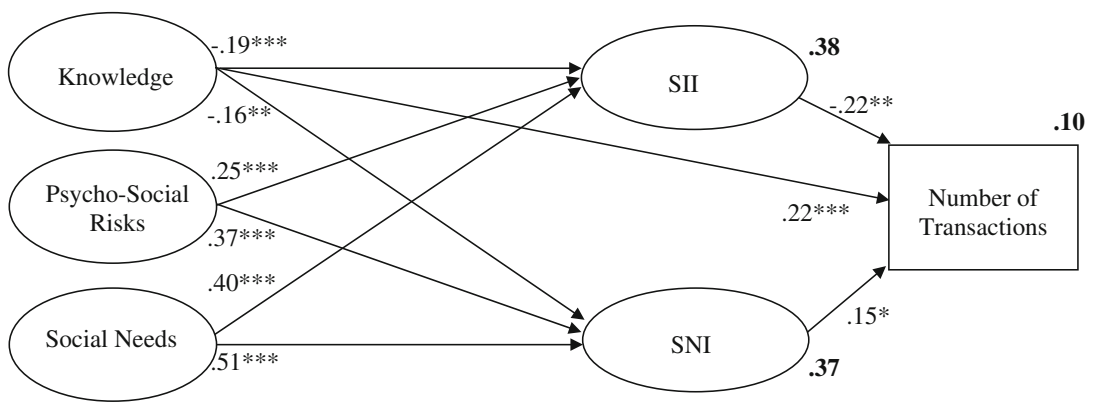




\section{Method}

Study 2 uses a $2 \times 3$ full-factorial between-subjects design with a hanging control group. We vary the type of interpersonal influence (informational vs. normative) and the valence of the influence (positively skewed toward stock A, neutral, positively skewed toward stock B). Participants may be exposed to informational influence, normative influence, or no interpersonal influence (hanging control group). A sample of 154 students (38\% female, mean age 23 years) volunteered to participate and were assigned randomly to each cell of the design. No significant differences exist among the cells in terms of gender, age, SNI, SII, knowledge, psycho-social risk, or social needs (all $F$-tests, $p>0.50$ ). Therefore, the randomization was effective.

Procedure

After entering the study room, each subject completed a questionnaire that asked about background characteristics (age, gender, and risk profile) and included the CSII scale (Bearden et al. 1989). ${ }^{3}$ The proctor told subjects there were no good or bad answers and all data would be treated anonymously and confidentially. We took care to avoid heightening the salience of social cues by including an explicit stop and a filler task between the administration of the questionnaire and the portion of the study in which subjects made their investment decisions. For all conditions, we told participants that they unexpectedly had received $€ 1,000$ (approximately $\$ 1,500$ ), not needed for their current expenses, that they could invest (in stock A or stock B) or put in a savings account that earned $2 \%$ interest.

All subjects also received objective information about the past performance of two shares, such that stock A had a historical rate of return of 5\% per year, and stock B had identical risk characteristics but a historical rate of return of $5.5 \%$. After being told that there were no transaction costs or taxes, the subjects indicated, using Likert scales, which portion of their money they would invest, and, if they had to invest, what percentage they would invest in stock A versus stock B.

The manipulation confronts subjects with an informational influence, normative influence, or no interpersonal influence. The study does not refer to the actual presence of relevant others to invoke feelings of observability, because in most cases, this influence would be absent during the real-life investment decisions.

We manipulate informational interpersonal influence by providing subjects with a summary of the information of 20 relevant investors. The summary was neutrally framed,

\footnotetext{
$\overline{{ }^{3} \text { In Studies } 2}$ and 3, we used the same items to measure CSII as in Study 1. To obtain an index score, we averaged respondents' responses for each type of interpersonal influence.
}

without reference to whether the subjects were closely or remotely related to these other investors, because the diagnosticity of and reliance on the source can vary across respondents and thus influence the decision. To manipulate the valence of informational interpersonal influence, we provide either favorable information about stock A ("15 investors mention positive information about stock $\mathrm{A}$ and negative information about $\mathrm{B}$, and 5 investors mention positive information about stock A and negative about B"), neutral information (" 10 investors mention positive information about stock $\mathrm{A}$ and negative about $\mathrm{B}$, and 10 investors mention negative information about stock $A$ and positive about B"), or favorable information about B ("15 investors mention positive information about $\mathrm{B}$ and negative about $\mathrm{A}$, and 5 investors mention positive information about A and negative about B").

The normative influence manipulation provides subjects with a summary of the personal opinions of 20 relevant investors, indicating these investors' opinion about what subjects should prefer, after making a personal request for these opinions. The manipulation of the valence of the normative interpersonal influence uses the same approach as that for informational influence (e.g., "based on their personal opinion 15 investors say you should prefer stock A, 5 investors say you should prefer stock B").

In the absence of any interpersonal influence (hanging control group), we expect subjects to prefer stock B, which provides superior historical payoff characteristics. Although Fama's (1991) efficient market hypothesis suggests that past trends in stock prices carry no useful information for consumers to trade on, consumers typically do take into consideration past information about investment products (Johnson and Tellis 2005). People prefer to buy past winners and sell past losers, even when neither should be preferred (Johnson et al. 2005). Yet if subjects receive interpersonal influences indicating that stock $\mathrm{A}$ is preferable, we expect it will lead them to select stock A, despite its lower historical returns. That is, subjects may choose the stock with lower expected returns because they (1) believe others have information that they can use to make better informed decisions, (2) expect to obtain social rewards or avoid social punishments, and/or (3) want to increase their self-image.

\section{Manipulation check}

Following Perdue and Summers (1986), we performed manipulation checks during a pilot test, using 38 students. The subjects performed the complete experiment receiving either informational or normative influence. We measured the strength of our manipulation by asking them to identify the degree to which the investors' evaluations were informational ("in the sense that the 20 investors provided information about the performance of stocks A and B") or 
normative ("in the sense that the 20 investors provided their personal opinion about what stocks you should buy"). Fivepoint Likert scales, ranging from 1 (totally disagree) to 5 (totally agree), indicate that subjects in the informational influence condition $(N=19)$ found the evaluations more informational than those in the normative influence condition $(N=19)\left(M_{\text {informational }}=3.53\right.$ vs. $\left.M_{\text {normative }}=2.32, p<0.001\right)$ and those in the normative influence condition found the evaluations more normative than those in the information influence condition $\left(M_{\text {informational }}=2.26\right.$ vs. $M_{\text {normative }}=4.00$, $p<0.001)$. Hence, the manipulation was effective.

\section{Results}

The analyses support our expectations. Confronting consumers with interpersonal influences significantly alters their investment decisions, especially their relative preference for different stocks $(F(6,147)=5.02, p<0.001)$. The amount of money invested, however, does not vary with interpersonal influence $(F(6,147)=1.44, p=0.20) .{ }^{4}$

Subjects in the informational influence scenarios significantly differ in their relative preference for stocks, depending on the valence of the information they receive $(F(2,66)=$ $13.40, p<0.001, \eta^{2}=0.29$ ). Similarly, those in the normative influence conditions significantly differ according to the valence of the normative message $(F(2,57)=2.62, p=0.081$, $\eta^{2}=0.08$ ), but at the less restrictive $10 \%$ level.

As we show in Table 3, subjects in the informational influence condition that favors stock A report a greater preference for stock A $(M=2.60)$ compared with those in the control condition $(M=3.23, t(48)=2.54, p=0.01)$. Subjects who receive normative influences in favor of stock A also tend to choose stock A more than the control group ( $M=3.05$ vs. $M=3.23$ ), but the difference is too small to distinguish from chance variation $(t(42)=0.83, p>0.10)$. When confronted with interpersonal influences that favor stock $\mathrm{B}$, subjects indicate a greater preference for this stock in the informational $(M=3.83, t(46)=2.33, p=0.02)$ and normative $(M=3.80, t(43)=2.02, p=0.05)$ setting compared with the control group.

The insignificant findings for the normative influence group in the stock A scenario and the lower significance of normative influence compared with informational influence in the stock B scenario can be explained in the following way. In all normative influence conditions, subjects confront injunctive norms, as they are told what they should do (Cialdini 2003, 2007). In comparison with descriptive norms that describe what others have done,

\footnotetext{
${ }^{4}$ We also studied the potential effect of domain-specific knowledge on investment behavior. Subjects' level of investment-related knowledge influences the amount of money invested (more knowledgeable subjects invest more) but not their relative preference for stocks. The same results apply to Study 3 .
}

injunctive norms may be less effective for changing behavior (Cialdini 2003, 2007), because they exert strong control effects, limit people's freedom, and often produce feelings of resentment or psychological reactance (Brehm 1966; Cialdini 2007). The arousal of psychological reactance in a social influence situation leads to a tendency to disagree with the communicator (Brehm 1966; Burnkrant and Cousineau 1975). The effect of normative influence in the stock A scenario may be particularly weak because it lacks persuasiveness as it was contrary to the objective information (Cialdini 2003: 109).

We performed separate tests to investigate the interaction effect of SNI on normative influence and SII on informational influence, because we posit that the impact of normative influences may be magnified for consumers who score high on SNI, whereas the impact of informational influences may be magnified for consumers scoring high on SII. Using a median split to divide the subjects into high or low susceptibility to interpersonal influence samples (cf. Aaker 1999), we find no significant interaction effects. That is, the effects of normative influence $(F(2,54)=$ $0.51, p=0.60)$ and informational influence $(F(2,63)=0.44$, $p=0.65$ ) on subjects' preference for stock A or stock B are not strengthened or attenuated by their susceptibility to each type of influence (Table 4). ${ }^{5}$

\section{Study 3}

Study 3 tests the effects of interpersonal influence in a voluntary setting rather than the involuntary setting of Study 2. We investigate whether CSII affects the likelihood of asking others' opinions and evaluations and if it moderates the strength of interpersonal influence.

\section{Method}

The method is similar to that for Study 2, except that the subjects are free to choose to make their investment decisions without receiving any interpersonal influence (hanging control group) or request either information (informational influence) or opinions (normative influence) from others about the stocks. For subjects requesting to receive interpersonal information or opinion, we varied the valence of the influence in a similar manner to Study 2 . Subjects remain unaware of the manipulation, because they receive blank envelopes labeled "information" or "opinion." A sample of 277 students (33\% female, mean age 23 years) volunteered to participate.

\footnotetext{
${ }^{5}$ We rule out the possibility that this insignificance is due to a traitstate incongruity (Shedletski and Endler 1974; Rusting 1999), because our measured "trait" CSII and the "state" of interpersonal influence both refer to the same domain: investment decisions.
} 
Table 3 Relative preference for stock A and B as a function of interpersonal influence in Study 2 and Study 3

\begin{tabular}{|c|c|c|c|c|c|c|}
\hline & \multicolumn{3}{|l|}{ Study 2} & \multicolumn{3}{|l|}{ Study 3} \\
\hline & $\begin{array}{l}\text { Informational } \\
\text { influence }\end{array}$ & $\begin{array}{l}\text { Normative } \\
\text { influence }\end{array}$ & $\begin{array}{l}\text { No } \\
\text { influence }\end{array}$ & $\begin{array}{l}\text { Informational } \\
\text { influence }\end{array}$ & $\begin{array}{l}\text { Normative } \\
\text { influence }\end{array}$ & No influence \\
\hline $\begin{array}{l}\text { Preference for A } \\
\text { Neutral position } \\
\text { Preference for B }\end{array}$ & $\begin{array}{l}\text { a: } 2.60^{\mathrm{c}, \mathrm{d}, \mathrm{e}, \mathrm{f}(25)} \\
\text { c: } 3.43^{\mathrm{a}(21)} \\
\text { e: } 3.83^{\mathrm{a}, \mathrm{b}, \mathrm{g}(23)}\end{array}$ & $\begin{array}{l}\text { b: } 3.05^{\mathrm{e}, \mathrm{f}(19)} \\
\mathrm{d}: 3.48^{\mathrm{a}(21)} \\
\text { f: } 3.80^{\mathrm{a}, \mathrm{b}, \mathrm{g}(20)}\end{array}$ & $\mathrm{g}: 3.28^{\mathrm{a}, \mathrm{e}(25)}$ & $\begin{array}{l}\text { a: } 2.21^{\mathrm{c}, \mathrm{d}, \mathrm{e}, \mathrm{f}, \mathrm{g}(70)} \\
\mathrm{c}: 3.65^{\mathrm{a}, \mathrm{b}, \mathrm{e}(57)} \\
\text { e: } 3.96^{\mathrm{a}, \mathrm{b}, \mathrm{c}, \mathrm{d}, \mathrm{g}(49)}\end{array}$ & $\begin{array}{l}\text { b: } 2.45^{\mathrm{c}, \mathrm{d}, \mathrm{e}, \mathrm{f,g}(22)} \\
\text { d: } 3.46^{\mathrm{a}, \mathrm{b}, \mathrm{e}(13)} \\
\text { f: } 3.93^{\mathrm{a}, \mathrm{b}(14)}\end{array}$ & $\mathrm{g}: 3.60^{\mathrm{a}, \mathrm{b}, \mathrm{e}(52)}$ \\
\hline
\end{tabular}

The preference for stocks is based on the following Likert scale: $1=$ invest $100 \%$ in stock A; $2=75 \%$ in stock A and $25 \%$ in stock B; $3=50 \%$ in stock A and $50 \%$ in stock B; $4=25 \%$ in stock A and $75 \%$ in stock B; $5=100 \%$ invest in stock B

Superscripts represent significant mean differences between cells based on independent sample $t$-tests $(p<0.05)$, and report cell sizes between brackets

\section{Procedure}

The procedure is similar to that of Study 2 with a few notable exceptions. Before the experiment started, we told subjects they could open one of two envelopes, containing either a summary of personal information or the personal opinion of 20 relevant investors, or else open no envelope. In the first part of the experiment, subjects made their investment decision after deciding whether and which type of interpersonal influence to receive. In the second part, they completed the CSII scale after finishing a filler task and taking a 10 min break, which we use to minimize the salience of the social cues.

\section{Results}

Of the total sample of 277 subjects, $176(64 \%)$ chose to open the envelope containing interpersonal information (informational influence), 49 (18\%) opened the envelope containing interpersonal opinions (normative influence), and $52(19 \%)$ did not open an envelope (control group). We use logistic regression to test whether each subject's level of SII and SNI determines whether he or she opened an envelope with information or opinions, respectively. Nei- ther dimension increases the overall percentage of correct classifications of subjects who open either the informational or the normative envelope (Nagelkerke $R^{2}$ values $<0.03$ ). The low significance may result from subjects' low level of knowledge $\left(M_{\text {know }}=2.32\right)$ and their resultant strong need for interpersonal information (i.e., $81 \%$ opened an envelope) to learn from other investors about appropriate investment behavior. Alternatively, the limited amount of objective information provided in the experiment may have led the subjects to ask for other investors' information and opinions, just to increase their confidence in their investment decision.

As in Study 2, the analyses again support our expectations that consumers who are confronted with interpersonal influences significantly alter their relative preference for each stock $(F(6,270)=30.78, p<0.001)$, but not the amount they invest $(F(6,270)=1.27, p=0.27)$. These results demonstrate that interpersonal influences affect consumers' investment decisions, irrespective of whether the setting is voluntary or involuntary. Subjects who choose to be exposed to informational influence differ significantly in their relative preference for stocks, depending on the valence of the information received $(F(2,173)=78.37$, $\left.p<0.001, \eta^{2}=0.48\right)$. Similarly, those who ask for normative

Table 4 Relative preference for stock A and B as a function of interpersonal influence and susceptibility to interpersonal influence in Study 2 and Study 3

\begin{tabular}{|c|c|c|c|c|c|c|c|c|}
\hline & \multicolumn{4}{|l|}{ Study 2} & \multicolumn{4}{|l|}{ Study 3} \\
\hline & \multicolumn{2}{|c|}{ Informational influence } & \multicolumn{2}{|c|}{ Normative influence } & \multicolumn{2}{|c|}{ Informational influence } & \multicolumn{2}{|c|}{ Normative influence } \\
\hline & Low SII & High SII & Low SNI & High SNI & Low SII & High SII & Low SNI & High SNI \\
\hline Preference for A & 2.40 & 2.73 & 3.00 & 3.10 & $2.49 * *$ & $1.91 * *$ & 2.40 & 2.50 \\
\hline Neutral position & 3.20 & 3.64 & 3.25 & 3.78 & 3.59 & 3.75 & 3.60 & 3.38 \\
\hline Preference for B & 3.83 & 3.82 & 3.88 & 3.75 & $3.81 *$ & $4.14^{*}$ & 3.80 & 4.00 \\
\hline
\end{tabular}

The preference for stocks is based on the following Likert scale: $1=$ invest $100 \%$ in stock $\mathrm{A} ; 2=75 \%$ in stock $\mathrm{A}$ and $25 \%$ in stock B; $3=50 \%$ in stock A and $50 \%$ in stock B; $4=25 \%$ in stock A and $75 \%$ in stock B; $5=100 \%$ invest in stock B

${ }^{*} p<0.10 ;{ }^{* *} p<0.01$ : Mann-Whitney $U$ tests are used to test for significant differences between low vs. high cells 
influences differ significantly in their choices according to the valence of the normative message $(F(2,46)=11.27$, $\left.p<0.001, \eta^{2}=0.33\right)$. Interpersonal influence exhibits a stronger effect in Study 3 than in Study 2 in terms of the variance explained, which suggests that subjects follow interpersonal influences more closely when they actively request them compared with when they receive them involuntarily. Furthermore, we again find that informational influence has a stronger influence than normative influence on consumers' investment choices.

As shown in Table 3, the subjects report a greater preference for stock A when they receive informational influences $(M=2.21)$ favoring stock A compared with those in the control condition $(M=3.60, t(120)=8.80, p<0.001)$. Subjects who receive normative influences $(M=2.45)$ in support of stock A also tend to favor stock A more strongly compared with the control group $(M=3.60, t(72)=4.92$, $p<0.001)$. When receiving interpersonal influence that favors stock B, subjects indicate a greater preference for this stock in both the informational $(M=3.96, t(99)=2.42, p=0.018)$ and the normative $(M=3.93, t(64)=1.34, p>0.10)$ settings compared with the control group, though the difference is not significant for the latter, likely because of the relatively strong preference for stock B in the control group.

As in Study 2, we again perform separate tests to investigate whether the dimensions of CSII moderate the impact of interpersonal influence. Median splits divide the sample of subjects into high or low susceptibility to interpersonal influence groups. In the voluntary setting of Study 3 , we observe a significant interaction effect between SII and informational influence; that is, the effect of informational influence $(F(2,173)=5.36, p=0.006)$ on subjects' preference for stock A or stock B is strengthened by subjects' SII (Table 4). However, as in Study 2, we do not find a significant interaction effect between SNI and normative influence $(F(2,46)=0.17, p=0.85)$. The relatively small cell sizes (i.e., the smallest cell contains 5 observations) in the normative setting make these results difficult to interpret and warrant additional research with larger samples.

\section{Discussion and conclusion}

\section{Discussion of results}

To the best of our knowledge, this paper is the first to investigate empirically the antecedents and consequences of CSII and the impact of interpersonal influences in an investment context. We provide a theoretical explanation for why some consumers are more susceptible to interpersonal influence in an investment context than are others, as well as what consequences this susceptibility may create.
Although existing literature implicitly assumes that susceptibility to interpersonal influence plays an important role only for conspicuous or (socially) visible products, we demonstrate its relevance for investments, a less conspicuous and less visible product category.

The results of Study 1 confirm our hypotheses and demonstrate that consumers are especially susceptible to interpersonal influences when they lack necessary investment-related knowledge, perceive investing to be a risky activity in terms of the associated psychological and social risks, and have strong social needs. Although extant literature pays little attention to the influence of social needs (cf. Batra et al. 2001), the results from Study 1 show that these needs have the greatest influence on CSII in an investment context. To increase our understanding of CSII in an investment situation, researchers should devote more attention to investing as a social activity (Shiller 1984; Hoffmann 2007) and its potential expressive benefits (Statman 2004). Another important finding from Study 1 reveals that consumers who are more susceptible to informational influences trade less, whereas those who are more susceptible to normative influences trade more.

Study 2 and Study 3 show how consumers, with varying levels of CSII, are affected by interpersonal influences in a voluntary and non-voluntary context. Overall, the results show that consumers strongly alter their preference for stocks when experiencing interpersonal influences, and make decisions that are in line with the valence of the social influence, even though this may result in selecting investments with lower past returns.

Study 2 and Study 3 display the differences between consumers who involuntary receive or actively (voluntary) request interpersonal influence. Consumers follow the information and opinions of others more closely when they can choose the type of interpersonal influence they obtain rather than when they are involuntary confronted with it. We also observe that SII strengthens the effect of informational influences on consumers' investment choices in the voluntary context but not in the involuntary context. This significant interaction effect does not appear to be a demand artifact, because more susceptible respondents are not more likely to open a corresponding envelope.

The overall pattern of findings of our three studies suggests that in comparison with normative influences, informational influences play a stronger role in shaping consumers' investment-related behavior. This result is consistent with prior studies that imply consumers are more motivated to build knowledge by requesting information from and observing their social environment rather than conforming to others' expectations as a means to mediate social punishments and rewards and/or improve their selfimages (Burnkrant and Cousineau 1975; Park and Lessig 1977; Mangleburg et al. 2004). 
Implications for marketing and public policy

This research has several important implications for marketing managers and public policymakers. In particular, by elaborating on the role of others in consumers' investment decision making, it can help marketers to better target and promote their products to clients.

Specifically, consumers who are susceptible to interpersonal influences when they make investment decisions will be attentive observers of others' product and portfolio choices and rely on the opinions of these others more often. These consumers therefore may be more responsive to certain types of advertising, such as testimonials, expert opinions, or celebrity endorsements. Furthermore, because these consumers likely find the social aspects of investing particularly important, a valuable marketing strategy would offer them the possibility of interacting with similar others and discussing their investment decisions, such as through an online broker's Web forum.

Another important implication for managers emerges from the finding that consumer innovativeness relates negatively to CSII (Clark and Goldsmith 2006). Since CSII relates negatively to consumers' level of investment-related knowledge, financially educating consumers may benefit both consumers and companies. Providing financial education makes consumers more independent and prudent investors. Moreover, it limits their susceptibility to interpersonal influences, which may prompt them to adopt new financial products and services more readily and earlier in the product life cycle. Marketers could capitalize on CSII by organizing "master classes," during which consumers can learn and talk about new financial products. Such meetings also may reduce consumers' perceived (psychosocial) risks and increase their confidence about making accurate investment decisions. Companies should strike a careful balance between confronting consumers with interpersonal influences (e.g., through bank employees) and letting them interact with those employees and relevant others, because consumers are most strongly influenced when they are free to ask others, not when they are involuntarily confronted with (company-driven) interpersonal influence. Facilitating consumers' interactions seems to provide the most effective strategy, though at the expense of less company control over the timing, frequency, and content of these interactions.

Finally, considering the strong connections between susceptibility to interpersonal influence and conformity (Clark and Goldsmith 2006) and between conformist behavior and herding (Hirschleifer 2001), public policymakers should take notice of the situations in which investors are more or less likely to be susceptible to interpersonal influences and monitor changes in investors' susceptibility over time. A steady rise in susceptibility may function as an early warning system for crashes and hypes related to conformist behavior.

Limitations and further research

Our study contains several limitations that provide interesting avenues for further research. First, though our research demonstrates both how susceptibility to interpersonal influences affects consumers' transaction frequency (Study 1) and how consumers change their investment decisions in the presence of such interpersonal influences (Study 2 and 3 ), it does not address how CSII and interpersonal influences may affect returns on investment portfolios. Additional research could link susceptibility to interpersonal influences to investors' returns and address the potentially different impacts of SII versus SNI.

Second, survey approaches, such as that we used in Study 1, may suffer from common-method variance, which may inflate (or deflate) relationships (Doty and Glick 1998). We checked for potential method bias by performing a Harman's single-factor test, using CFA (Podsakoff et al. 2003), and find poor fit for the one-factor model $\left(\chi^{2} / d f=\right.$ 7.44; $\mathrm{GFI}=0.75 ; \mathrm{CFI}=0.60$; RMSEA $=0.15$ ), which suggests common-method variance does not pose a serious threat for Study 1. However, a selection bias also could affect the results of Study 1, because our respondents come from investment-related Web sites and were willing to invest their free time to complete the questionnaire. Therefore, they likely have a greater interest in investment research and knowledge than does the general population. Because visitors to these Web sites can post messages and interact with others, it is also more likely that these respondents perceive investing as a "social activity" (Shiller 1984).

Third, the homogeneous samples of Study 2 and 3 and the specific context of all studies (investing in stocks) warrant follow-up studies to investigate whether the effects we find in the voluntary and involuntary contexts hold for different situations (e.g., bonds, mortgages) and different demographic and socio-economic groups.

Fourth, Study 2 uses psychological reactance to explain the less significant impact of normative influence, but we do not measure it. In Study 3, we gauged subjects' reactance by measuring the extent to which the interpersonal influences irritated them. As we expected, reactance was relatively low in this voluntary setting, which may help explain the stronger impact of normative influences in Study 3. However, further studies are needed to draw any final conclusions about the impact of reactance.

Fifth, the current measure of CSII focuses on personal influences, that is, the influence of friends and relatives. Additional research could broaden this concept by considering the susceptibility of consumers to other, less closely 
related, sources of information, such as business experts, bank employees, or investment-related Web sites. Such studies offer a rich venue for research, especially considering the tremendous growth of financial information received from online investment clubs and Web sites.

Sixth, similar to most existing consumer research, our study focuses on the effect of knowledge per se while investigating CSII in an investment context. However, differences may exist between consumers' objective and subjective knowledge, i.e., knowledge miscalibration (Alba and Hutchinson 2000). Research should investigate how knowledge miscalibration may affect susceptibility to and the impact of interpersonal influence in an investment context. Subjective knowledge may be more strongly associated with CSII than objective knowledge. Consumers who believe they have a high level of investment-related knowledge may find it unnecessary to ask others for advice, regardless of their level of objective knowledge. Moreover, they may be less influenced by interpersonal influences. Consumers also might overestimate their ability to judge the validity of the information and opinions provided by others, which would make them vulnerable to interpersonal persuasion attempts by salespersons for example. Finally, knowledge miscalibration could lead to overconfidence and thus affect investment performance through overtrading (Morrin et al. 2002; Odean and Barber 2000).

Despite these limitations, this research contributes significantly to consumer behavior and marketing literature and offers important insights for marketing practice by shedding light on the processes by which reference group influences operate in an investment context and affect consumers' investment decisions. Providing such insights may help consumers to make better informed investment decisions and responds to the recent call by Bazerman (2001) for a more consumer-focused approach in the field of financial services.

Open Access This article is distributed under the terms of the Creative Commons Attribution Noncommercial License which permits any noncommercial use, distribution, and reproduction in any medium, provided the original author(s) and source are credited.

\section{References}

Aaker, J. L. (1999). The malleable self: The role of self-expression in persuasion. JMR, Journal of Marketing Research, 36, 45-57. doi: $10.2307 / 3151914$.

Alba, J. W., \& Hutchinson, J. W. (1987). Dimensions of consumer expertise. The Journal of Consumer Research, 13, 411-454. doi:10.1086/209080.

Alba, J. W., \& Hutchinson, J. W. (2000). Knowledge calibration: What consumers know and what they think they know. The Journal of Consumer Research, 27, 123-156. doi:10.1086/314317.
Anderson, J. C., \& Gerbing, D. W. (1988). Structural equation modeling in practice: A review and recommended two-step approach. Psychological Bulletin, 103, 411-423. doi:10.1037/ 0033-2909.103.3.411.

Bagozzi, R. P., \& Yi, Y. (1988). On the evaluation of structural equation models. Journal of the Academy of Marketing Science, 16, 74-94. doi:10.1007/BF02723327.

Barber, B. M., \& Odean, T. (2000). Too many Cooks spoil the profits: The performance of investment clubs. Financial Analysts Journal, 70, 17-25 (January/February)doi:10.2469/faj.v56.n1.2326.

Batra, R., Homer, P. M., \& Kahle, L. R. (2001). Values, susceptibility to normative influence, and attribute importance weights: A nomological analysis. Journal of Consumer Psychology, 11, 115128. doi:10.1207/S15327663JCP1102 04.

Bauer, R., Cosemans, M., \& Eichholtz, P. M. A. (2007). The performance and persistence of individual investors: Rational agents or tulip maniacs? EFA 2007 Ljubljana Meetings Paper.

Bazerman, M. H. (2001). Consumer research for consumers. The Journal of Consumer Research, 27, 499-504. doi:10.1086/ 319624.

Bearden, W. O., \& Rose, R. L. (1990). Attention to social comparison information: An individual difference factor affecting consumer conformity. The Journal of Consumer Research, 16, 461-471. doi:10.1086/209231.

Bearden, W. O., Netemeyer, R. G., \& Teel, J. E. (1989). Measurement of consumer susceptibility to interpersonal influence. The Journal of Consumer Research, 15, 473-481. doi:10.1086/ 209186.

Bearden, W. O., Netemeyer, R. G., \& Teel, J. E. (1990). Further validation of the consumer susceptibility to interpersonal influence scale. Advances in Consumer Research, 17, Provo, UT: ACR, 770-776.

Bikhchandani, S., \& Sharma, S. (2000). Herd behavior in financial markets: A review. IMF Staff Papers, 3(47), 279-310.

Bikhchandani, S., Hirschleifer, D., \& Welch, I. (1992). A theory of fads, fashion, custom, and cultural change as informational cascades. The Journal of Political Economy, 100, 992-1026. doi:10.1086/261849.

Bloch, P. H., Ridgway, N. M., \& Sherrell, D. L. (1989). Extending the concept of shopping: An investigation of browsing activity. Journal of the Academy of Marketing Science, 17, 13-21. doi:10.1007/BF02726349.

Brehm, J. W. (1966). A theory of psychological reactance. New York: Academic.

Bristol, T., \& Mangleburg, T. F. (2005). Not telling the whole story: teen deception in purchasing. Journal of the Academy of Marketing Science, 33, 79-95. doi:10.1177/0092070304269754.

Browning, M., \& Crossley, T. F. (2001). The life-cycle model of consumption and saving. The Journal of Economic Perspectives, $15,3-22$.

Burnkrant, R. E., \& Cousineau, A. (1975). Informational and normative social influence in buyer behavior. The Journal of Consumer Research, 2, 206-215. doi:10.1086/208633.

Chao, A., \& Schor, J. B. (1998). Empirical tests of status consumption: Evidence from women's cosmetics. Journal of Economic Psychology, 19, 107-131. doi:10.1016/S0167-4870 (97)00038-X.

Cheek, J. M., \& Buss, A. H. (1981). Shyness and sociability. Journal of Personality and Social Psychology, 41, 330-339. doi:10.1037/ 0022-3514.41.2.330.

Chin, W. W. (2000). Frequently asked questions - partial least squares \& PLS-graph. Home Page. [On-line]. Available: http://disc-nt. cba.uh.edu/chin/plsfaq.htm. Access 17 July 2008.

Cialdini, R. B. (2003). Crafting normative messages to protect the environment. Current Directions in Psychological Science, 12, 105-109. doi:10.1111/1467-8721.01242. 
Cialdini, R. B. (2007). Descriptive social norms as underappreciated sources of social control. Psychometrika, 72, 263-268. doi:10.1007/s11336-006-1560-6.

Cialdini, R. B., \& Goldstein, N. J. (2004). Social influence: Compliance and conformity. Annual Review of Psychology, 55, 591-621. doi:10.1146/annurev.psych.55.090902.142015.

Cialdini, R. B., \& Trost, M. R. (1998). Social influence: Social norms, conformity, and compliance. In D. T. Gilbert, S. T. Fiske, \& G. Lindzey (Eds.), The handbook of social psychology (pp. 151192, 4th ed.). Boston: McGraw-Hill.

Clark, R. A., \& Goldsmith, R. E. (2005). Market mavens: Psychological influences. Psychology and Marketing, 22, 289-312. doi:10.1002/mar.20060.

Clark, R. A., \& Goldsmith, R. E. (2006). Interpersonal influence and consumer innovativeness. International Journal of Consumer Studies, 30, 34-43. doi:10.1111/j.1470-6431.2005.00435.x.

Cox, D., \& Bauer, R. A. (1964). Self-confidence and persuasibility in women. Public Opinion Quarterly, 28, 453-466. doi:10.1086/ 267266.

De Bondt, W. F. M. (1998). A portrait of the individual investor. European Economic Review, 42, 831-844. doi:10.1016/S00142921(98)00009-9.

Deutsch, M., \& Gerard, H. B. (1955). A study of normative and informative social influences upon individual judgment. Journal of Abnormal and Social Psychology, 51, 629-636. doi:10.1037/ h0046408.

DNB (2006). DNB Statistical Bulletin June 2006.

Doty, D. H., \& Glick, W. H. (1998). Common methods bias: Does common methods variance really bias results? Organizational Research Methods, 1, 374-406. doi:10.1177/109442819814002.

D'Rozario, D., \& Choudhury, P. K. (2000). Effect of assimilation on consumer susceptibility to interpersonal influence. Journal of Consumer Marketing, 17, 290-307. doi:10.1108/07363760010335321.

Edgett, S. (1994). The traits of successful new service development. Journal of Services Marketing, 8, 40-49. doi:10.1108/ 08876049410065606.

Fama, E. F. (1991). Efficient capital markets: II. The Journal of Finance, 46, 1575-1617. doi:10.2307/2328565.

Festinger, L. (1954). A theory of social comparison processes. Human Relations, 7, 117-140. doi:10.1177/001872675400700202.

Fornell, C., \& Larcker, D. F. (1981). Structural equation models with unobservable variables and measurement error: Algebra and statistics. JMR, Journal of Marketing Research, 18, 382-388. doi: $10.2307 / 3150980$

Furse, D., Punj, G., \& Stewart, D. W. (1984). A typology of individual search strategies among purchasers of new automobiles. The Journal of Consumer Research, 10, 417-431. doi:10.1086/208980.

Gilly, M. C., Graham, J. L., Wolfinbarger, M. F., \& Yale, L. J. (1998). A dyadic study of interpersonal information search. Journal of the Academy of Marketing Science, 26, 83-100. doi:10.1177/ 0092070398262001.

Hirschleifer, D. (2001). Investor psychology and asset pricing. The Journal of Finance, 56, 1533-1597. doi:10.1111/0022-1082. 00379.

Hirschleifer, D., \& Teoh, S. H. (2003). Herd behaviour and cascading in capital markets: A review and synthesis. European Financial Management, 9, 25-66. doi:10.1111/1468-036X.00207.

Hoffmann, A. O. I. (2007). Investors' needs and the investment professional: Lessons from marketing. The Journal of Investment Consulting, 8, 80-91.

Hong, H., Kubik, J. D., \& Stein, J. C. (2004). Social interaction and stock market participation. The Journal of Finance, 59, 137-163. doi:10.1111/j.1540-6261.2004.00629.x.

Janis, I. L. (1954). Personality correlates of susceptibility to persuasion. Journal of Personality, 22, 504-518. doi:10.1111/ j.1467-6494.1954.tb01870.x.
Janis, I. L. (1955). Anxiety indices related to susceptibility to persuasion. Journal of Abnormal Psychology, 51, 663-667. doi: $10.1037 / \mathrm{h} 0046765$.

Johnson, J., \& Tellis, G. J. (2005). Blowing bubbles: Heuristics and biases in the run-up of stock prices. Journal of the Academy of Marketing Science, 33, 486-503. doi:10.1177/0092070305277381.

Johnson, J., Tellis, G. J., \& Macinnis, D. J. (2005). Losers, winners, and biased trades. The Journal of Consumer Research, 32, 324 329. doi: $10.1086 / 432241$.

Kahle, L. R. (1995). Observations: Role-relaxed consumers: A trend of the nineties. Journal of Advertising Research, 35, 66-71.

Kaplan, L. B., Szybillo, G. J., \& Jacoby, J. (1974). Components of perceived risk in product purchase: A cross-validation. The Journal of Applied Psychology, 59, 287-291. doi:10.1037/ h0036657.

Kiecker, P., \& Hartman, C. L. (1993). Purchase pal use: Why buyers choose to shop with others. 1993 AMA Winter Educators' Conference Proceedings. Chicago: American Marketing Association.

Kindleberger, C. P. (2000). Manias, panics, and crashes. A history of financial crises (4th ed.). New York: Wiley.

Kleijnen, M., de Ruyter, K., \& Andreassen, T. W. (2005). Image congruence and the adoption of service innovations. Journal of Service Research, 7, 343-359. doi:10.1177/1094670 504273978.

Kropp, F., Lavack, A. M., \& Holden, S. J. S. (1999). Smokers and beer drinkers: Values and consumer susceptibility to interpersonal influence. Journal of Consumer Marketing, 16, 536-557. doi:10.1108/07363769910297498.

Lascu, D. N., Bearden, W. O., \& Rose, R. L. (1995). Norm extremity and interpersonal influences on consumer conformity. Journal of Business Research, 32, 201-212. doi:10.1016/0148-2963(94) 00046- $\mathrm{H}$

LaTour, S. A., \& Manrai, A. K. (1989). Interactive impact of informational and normative influence on donations. JMR, Journal of Marketing Research, 26, 327-335. doi:10.2307/ 3172904.

Locander, W. B., \& Hermann, P. W. (1979). The effect of selfconfidence and anxiety on information seeking in consumer risk reduction. JMR, Journal of Marketing Research, 16, 268-274. doi: $10.2307 / 3150690$.

Mangleburg, T. F., Doney, P. M., \& Bristol, T. (2004). Shopping with friends and teens' susceptibility to peer influence. Journal of Retailing, 80, 101-116. doi:10.1016/j.jretai.2004.04.005.

Mascarenhas, O. A. J., \& Higby, M. A. (1993). Peer, parent, and media influences in teen apparel shopping. Journal of the Academy of Marketing Science, 21, 53-58. doi:10.1177/ 0092070393211007.

Maslow, A. H. (1954). Motivation and personality. New York: Harper and Row.

McGuire, W. J. (1968). Personality and susceptibility to social influences. In E. F. Borgatta, \& W. W. Lambert (Eds.), Handbook of personality theory and research (pp. 1130-1187). Chicago: Rand McNally.

Meyer, D. J. C., \& Anderson, H. C. (2000). Preadolescents and apparel purchasing: conformity to parents and peers in the consumer socialization process. Journal of Social Behavior and Personality, 15, 243-257.

Miller, N. J. (1998). Susceptibility of consumers to normative and informational influences in selecting colors for apparel. Perceptual and Motor Skills, 87, 1131-1136.

Mitchell, V.-W., \& McGoldrick, P. J. (1996). Consumers' risk reducing strategies: A review and synthesis. International Review of Retail, Distribution and Consumer Research, 6, 1-33. doi:10.1080/09593969600000001.

Morrin, M., Jacoby, J., Johar, V. G., He, X., Kuss, A., \& Mazursky, D. (2002). Taking stock of stock brokers: Exploring momentum 
versus contrarian investor strategies and profiles. The Journal of Consumer Research, 29, 188-198. doi:10.1086/341570.

Mourali, M., Laroche, M., \& Pons, F. (2005). Individualistic orientation and consumer susceptibility to interpersonal influence. Journal of Services Marketing, 19, 164-173. doi:10.1108/ 08876040510596849.

Netemeyer, R. G., Bearden, W. O., \& Sharma, S. (2003). Scaling procedures: Issues and applications. Thousand Oaks, California: Sage.

Nunnally, J. C., \& Bernstein, I. H. (1994). Psychometric theory (3rd ed.). New York: McGraw-Hill.

O'Cass, A., \& McEwen, H. (2004). Exploring consumer status and conspicuous consumption. Journal of Consumer Behaviour, 4, 25-39. doi:10.1002/cb.155.

Odean, T., \& Barber, B. M. (2000). Trading is hazardous to your wealth: The common stock investment performance of individual investors. The Journal of Finance, 55, 773-806. doi:10.1111/ 0022-1082.00226.

Park, C. W., \& Lessig, P. V. (1977). Students and housewives: Differences in susceptibility to reference group influence. The Journal of Consumer Research, 4, 102-110. doi:10.1086/208685.

Perdue, B. C., \& Summers, J. O. (1986). Checking the success of manipulations in marketing experiments. JMR, Journal of Marketing Research, 23, 317-326. doi:10.2307/3151807.

Podsakoff, P. M., MacKenzie, S. B., Lee, J.-Y., \& Podsakoff, N. P. (2003). Common method biases in behavioral research: A critical review of the literature and recommended remedies. The Journal of Applied Psychology, 88, 879-903. doi:10.1037/00219010.88.5.879.

Ratner, R. K., \& Kahn, B. E. (2002). The impact of private versus public consumption on variety-seeking behavior. The Journal of Consumer Research, 29, 246-257. doi:10.1086/341574.

Rusting, C. L. (1999). Interactive effects of personality and mood on emotion-congruent memory and judgment. Journal of Personal- ity and Social Psychology, 77, 1073-1086. doi:10.1037/00223514.77.5.1073.

Shedletski, R., \& Endler, N. S. (1974). Anxiety: The state-trait model and the interaction model. Journal of Personality, 42, 511-527. doi:10.1111/j.1467-6494.1974.tb00690.x.

Shiller, R. J. (1984). Stock prices and social dynamics. Brookings Papers on Economic Activity, 2, 457-498. doi:10.2307/2534436.

Shiller, R. J. (1995). Conversation, information, and herd behavior. The American Economic Review, 85, 181-185.

Sirgy, M. J. (1982). Self-concept in consumer behavior: A critical review. The Journal of Consumer Research, 9, 287-300. doi:10.1086/208924.

Sirgy, M. J. (1985). Using self-congruity and ideal congruity to predict purchase intention. Journal of Business Research, 13, 195-206. doi:10.1016/0148-2963(85)90026-8.

Statman, M. (2004). What do investors want? Journal of Portfolio Management, 30, 153-161.

Steenkamp, J. B. E. M., \& Gielens, K. (2003). Consumer and market drivers of the trial probability of new consumer packaged goods. The Journal of Consumer Research, 30, 368-384. doi:10.1086/ 378615.

Storey, C., \& Easingwood, C. J. (1999). Types of new product performance: Evidence from the consumer financial services sector. Journal of Business Research, 46, 193-203. doi:10.1016/ S0148-2963(98)00022-8.

VEB (2002). Is beleggen uit en sparen in? Effect, 5. (In Dutch).

Yim, C. K., Chan, K. W., \& Hung, K. (2007). Multiple reference effects in service evaluations: Roles of alternative attractiveness and self-image congruity. Journal of Retailing, 83, 147-157. doi:10.1016/j.jretai.2006.10.011.

Zhou, R., \& Pham, M. T. (2004). Promotion and prevention across mental accounts: When financial products dictate consumers' investment goals. The Journal of Consumer Research, 31, 125135. doi: $10.1086 / 383429$. 